\title{
OCEan Circulation InFluencing THE EXXON VALDEZ OIL SPILL
}

\author{
By Thomas C. Royer, \\ John A. Vermersch, \\ Thomas J. Weingartner, \\ H.J. Niebauer and Robin D. Muench
}

$\mathrm{I}_{\mathrm{N}}$  oll spill occurred in one of its largest estuaries: Alaska 's Prince William Sound. Observations of the spill trajectory serve to delineate the circulation within the sound and along the southern coast of Alaska. This region has very high rates of freshwater discharge and intense wind stresses: the average annual amount of fresh water entering the Northeast Pacific drainage system is at least $20 \%$ larger than the Mississippi River system, and the seasonal signals of wind stress and wind stress curl here are the largest in the North Pacific. Even as the oil was being released in the sound, it came under the influence of this coastal circulation. The spilled oil and subsequently released surface drifters have served as tracers that can be used to examine our knowledge of the processes affecting regional coastal flow. This knowledge might be applied to coastal processes elsewhere.

Oceanographic and meteorological processes played an important role in distributing the spilled oil within the sound and along the coast after the accident. Were these processes unusual or typical of the region and time of year? How, if at all, did they contribute to the spill? Are they helping to remove or concentrate the oil spill debris? How have the spill observations and other recently acquired data improved our knowledge of the regional oceanography?

\section{The Setting}

The coastal orography which defines Prince William Sound (Fig. 1,p. 4) affects the coastal circulation in several ways. The water motion is restricted by topography, and coastal mountains alter the meteorology. This vast coastal mountain range extends from British Columbia throughout southeast and southcoast Alaska to Kodiak Island. The heights of the coastal mountains exceed $4 \mathrm{~km}$. Since the height of the tropopause is beneath that elevation at this latitude, atmospheric disturbances are usually blocked from moving inland. This regional tendency for orographic blockage of storm systems occurs along the northeast Pacific from British Columbia to the northern Gulf of Alaska. The adiabatic elevation of the moisture-laden

Thomas C. Royer, Thomas J. Weingartner and H.J. Niebauer, Institute of Marine Science. University of Alaska, Fairbanks, Alaska 99775: John A. Vermersch, Exxon Production Research Company. P. O. Box 2189. Houston. Texas 77252; Robin D. Muench. Science Applications International Corporation. 13400B Northrup Way, Suite 36. Bellevue, WA 98005. air masses causes very high precipitation rates along the coast, especially at higher elevations. Annual precipitation in excess of $8 \mathrm{~m}$ has been recorded within Prince William Sound. Because the coastal drainage region is narrow $(<100 \mathrm{~km})$, the majority of the freshwater entering the coastal regime is from small, short streams rather than from large river networks. Therefore, the freshwater enters as a distributed or line source of low density water rather than a single, large source like the Mississippi River discharge. Since Prince William Sound is hundreds of kilometers downstream from the beginning of the line source, it experiences a cumulative effect from this coastal discharge.

The same storm systems that provide precipitation also supply wind stresses that create coastal convergences in the ocean and the downwelling of surface waters. Easterly winds associated with the storms move surface water to the right of the wind in the northern hemisphere causing an accumulation or convergence of surface water near the coast. These cyclonic (counterclockwise) wind systems are steered by the coastal mountains and fed by latent heat from the coastal precipitation. The source of energy for these processes is the North Pacific Ocean, from which the atmosphere receives its moisture and heat. Wind stresses and buoyancy flux here exhibit large seasonal signals. They are controlled by the North Pacific High in summer and the Aleutian Low in winter. The minimum wind stress occurs in summer (June, July and August) and the maximum occurs in winter (December, January and February). The time of the maximum precipitation leads wind stress by two to three months, and in winter most precipitation is stored as snow in the coastal mountain ranges (see Table of Contents, p.1). Coastal downwelling and associated convergence maintains freshwater as a nearshore feature and enhances the density related nature of that flow. The ensuing coastal setup drives the sea level slope component of the coastal current.

The predominant coastal circulation feature in the northern Gulf of Alaska is the relatively dilute Alaska Coastal Current (ACC), which has an intense westward velocity (20-180 $\mathrm{cm} \mathrm{s}^{-1}$ ) and is confined mainly to within $20 \mathrm{~km}$ of the shore. In the upper $100 \mathrm{~m}$, density driven transport is about $2 \times 10^{5} \mathrm{~m}^{3} \mathrm{~s}^{-1}$ and seasonal fluctuations are about $1 \times 10^{5} \mathrm{~m}^{3} \mathrm{~s}^{-1}$. The current component due to the sea surface tilt is always west- 

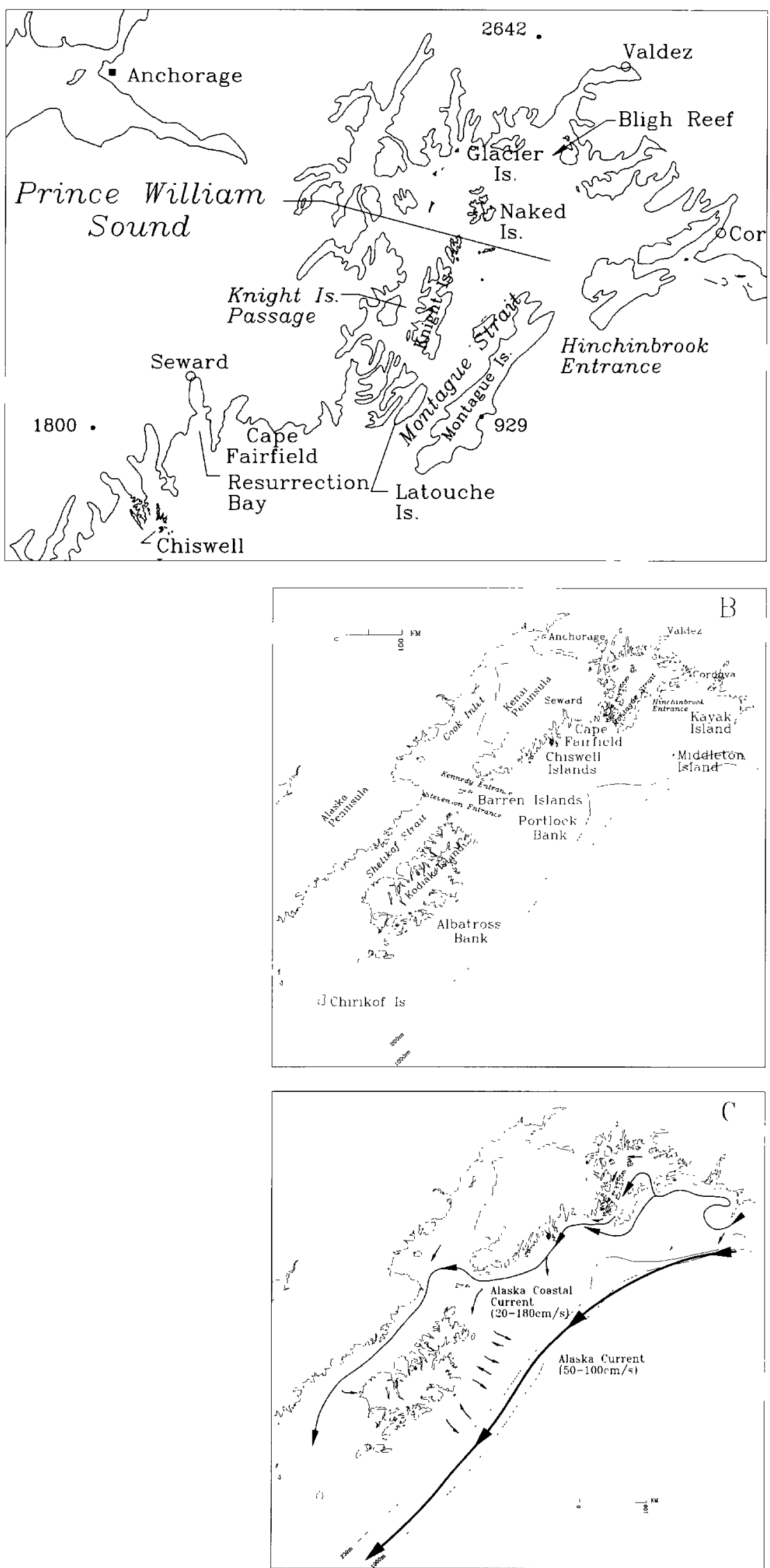

Fig. 1: (a) Prince William Sound; (b) the Northwest Gulf of Alaska; $(c)$ schematic surface circulation for Northwest Gulf of Alaska.Heights and depthsinmeters. ward, so the bottom flow beneath the coastal current is usually westward at a few centimeters per second. Offshore of this high speed flow there is a tendency for density-induced flow reversals, with near-surface speeds of $10-25 \mathrm{~cm} \mathrm{~s}^{-1}$. These reversals are more transient and their transports are significantly smaller than those associated with the ACC. Modal analysis of currents, winds and fresh water discharge indicates that the primary mode of the alongshore flow component is nearly all due to sea level slopes and is related to the upwelling index, a measure of the onshore-offshore Ekman transport. The upwelling index is related to the alongshore wind and hence, the coastal convergences and divergences. The second mode of the alongshore flow consists of a separate upper layer current that corresponds to water density variations due to runoff. With respect to the cross-shore flow component, the first mode is nearly all due to sea surface slopes and is also related to the upwelling index. The second mode is related to the runoff and shows offshore motion at the surface and onshore flow near the bottom (Johnson et al., 1988).

These flow features are disrupted by coastal topography illustrated by the flow upstream of Prince William Sound. Kayak Island (Fig. 1) extends across the shelf and diverts the coastal flow offshore toward the shelf break (Ahlnaes et al., 1987). This causes numerous eddies to form in the lee of the island. Other coastal irregularities are expected to have a similar effect on the shelf circulation and will enhance crossshelf mixing. There is also evidence that the eddy energy level increases during periods of maximum flow (Johnson et al., 1988), which implies enhanced mixing of coastal water across the shelf.

\section{Regional Circulation}

Upstream of Prince William Sound the coastal current is fed by freshwater from numerous glaciers such as the Bering and Malaspina. The sea-surface temperature gradients in this high latitude region do not imply the dynamics as much as do water temperature contrasts in warmer waters (Ahlnaes and Royer, 1989). However, the water has very high sediment loads associated with the glacial grinding of the underlying bedrock into a fine silt $(0.004-0.0625 \mathrm{~mm})$ and clay $(<0.004 \mathrm{~mm}$ ) (Hampton et al.,1986). The swift, short streams also contribute sediment to the coastal flow. These sediments permit the tracing of the coastal surface current using satellite remote sensing in the visible band. The flow into Prince William Sound through Hinchinbrook Entrance can be seen in the Coastal Zone Color Scanner image (Fig. 2). The circulation pattern disappears within Prince William Sound as the sediments sink or as the sediment-laden waters flow beneath lower salinity, sediment-free waters.

Prince William Sound (Fig. 1) consists of a central region with a maximum depth of $800 \mathrm{~m}$, numerous fjords in the northern and western reaches, and narrow passages in the southwestern section. The major inflow into Prince William Sound is through Hinchinbrook Entrance, which has a channel width of $10 \mathrm{~km}$ and a maximum depth of $360 \mathrm{~m}$. At this channel the Alaska Coastal Current splits; a portion enters the sound, and 


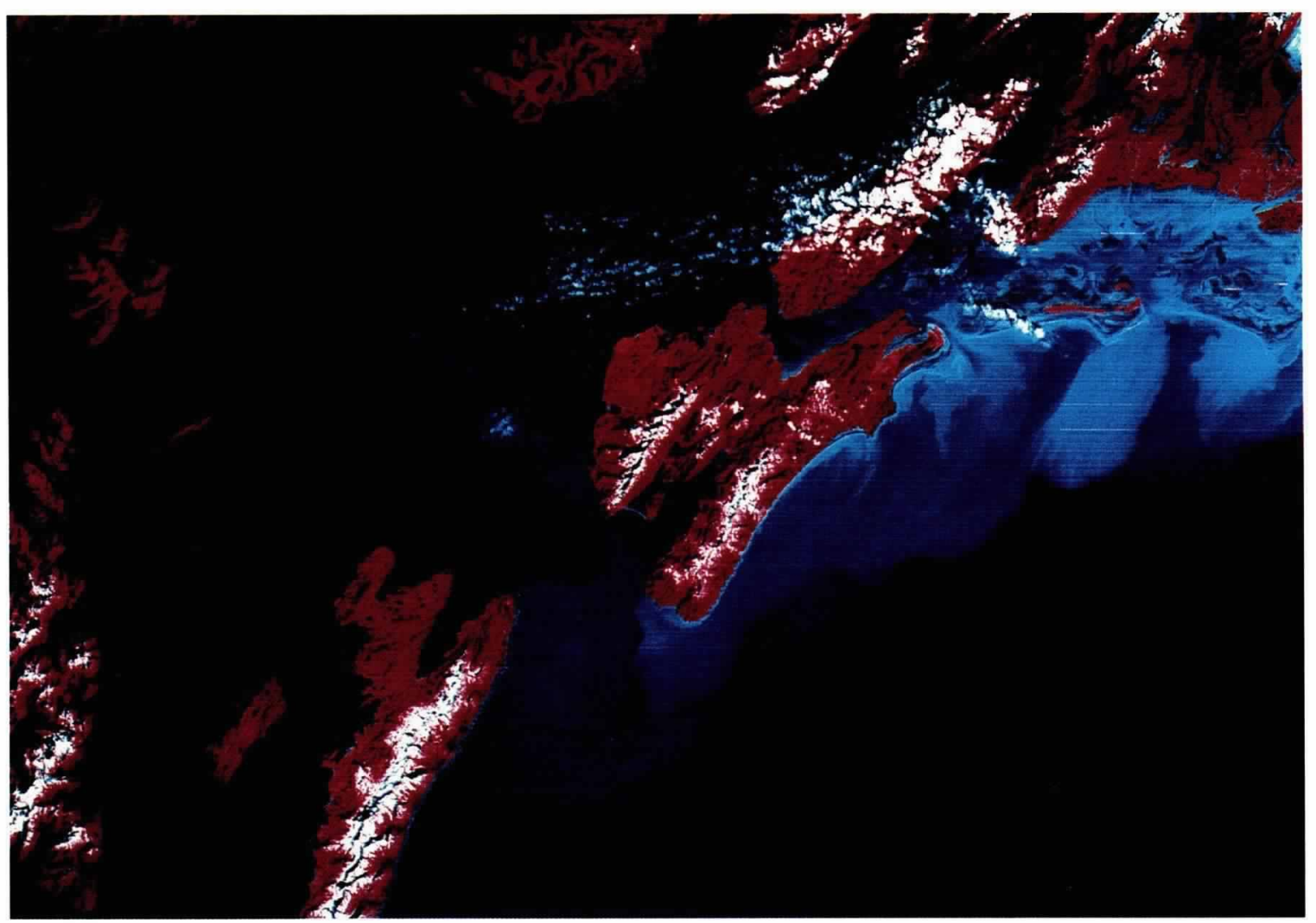

Fig. 2. Coastal Zone Color Scanner image of the entrance to Prince William Sound showing sediment inflow into the sound.

the remainder proceeds along the southeastern coast of Montague Island (Fig. 2). The factors determining what portion enters the sound are not well known, but the possible influences include water density gradients, atmospheric pressure differences inside and outside the sound, local winds and alongshore pressure gradients. The coastal flow is approximately perpendicular to the entrance, thus inertial flow effects might be important. High speeds might increase the inertial radius so that the flow might cross this gap before it was able to turn right, into the sound. This would force a greater portion of the flow to bypass Hinchinbrook Entrance (See Fig. 2). The seasonal changes in the internal Rossby radius (another measure of the turning ability of the flow) range from $5-20 \mathrm{~km}$ and can also be expected to influence the amount of water entering the sound.

Computations of density-driven current from twenty-three temperature and salinity sections across Hinchinbrook Entrance since 1974 are inconclusive as to the direction of the flow. They reveal an average outflow of $1.4 \times 10^{4} \mathrm{~m}^{3} \mathrm{~s}^{-1}$, but the standard deviation is more than five times this mean. Other evidence shows a predominance of inflow through Hinchinbrook Entrance. That evidence includes current meter measurements in 1977 and 1978 and Acoustic Doppler Current Profiler (ADCP) data during four cruises since 1986. These data, along with the hydrographic and current meter data for Hinchinbrook Entrance, were analyzed for the first time in response to the spill. For the December 1986 ADCP section, a complex flow was observed with inflow on the western side of the entrance and outward (southward) flow on the eastern side, a similar pattern as seen in Fig. 2. The 1977-78 current meter mooring was located near the center of the entrance and hence was in a region of variablydirected currents. The few ADCP cross-channel transects available also indicate a complicated and variable flow structure in Hinchinbrook Entrance. In spite of these difficulties, flow through the entrance is assumed to be horizontally uniform. The transport estimates indicate an inflow of about $3 \times 10^{5} \mathrm{~m}^{3} \mathrm{~s}^{-1}$, which is most likely an overestimate. Other evidence that there is persistent inflow into Prince William Sound from the Gulf of Alaskathrough Hinchinbrook Entrance is derived from drifting buoys which have entered the sound through this channel (Royer et al., 1979 and unpublished data) and from persistent surface water sediment load patterns. Additionally, a numerical model based upon seasonal hydrographic data and sea level differences at Hinchinbrook Entrance and Montague Strait also indicates inflow through Hinchinbrook Entrance (Isaji, ASA, pers. comm.). These results are consistent with the numerical models of Venkatesh (1990) and Galt and Payton (1990).

There is a cyclonic circulation cell within Prince William Sound, (Muench and Schmidt, 1975) whose center is approximately $30 \mathrm{~km}$ north of the entrance as suggested in Fig. 2. This circulation is maintained by precipitation and runoff emanating from the fjords and embayments that rim the sound. Local topography confines the winds to flow along isobaths. Typically, 


\section{The Alaska Current}

serves as a dynamic

outer boundary along

the shelf break. low pressure atmospheric systems in the Gulf of Alaska will cause down-fjord winds that converge in the central sound and flow out through Hinchinbrook Entrance and Montague Strait. The relatively cold ice fields and warm surface waters of the sound create conditions ideal to the formation of catabatic winds which flow down the fjords. especially those containing glaciers. Each of these processes tend to transport surface water out of the upper reaches of the sound. In the northern sound the flow is weak $\left(<10 \mathrm{~cm} \mathrm{~s}^{-1}\right)$ and westward, ultimately flowing southwestward down either Knight Island passage or Montague Strait (Fig. 1). Water flowing southwestward through Knight Island Passage can either enter lower Montague Strait or can exit directly into the gulf through Latouche, Elrington, Prince of Wales or Bainbridge passages. These passages-located to the northwest of lower Montague Strait - are narrow $(<2 \mathrm{~km})$ and shallow $(<35 \mathrm{~m})$, and the volume of outflow is small relative to that in the strait. Based upon ADCP cross-channel transects, the assumption of uniform cross-channel flow in Montague Strait is valid. Transport estimates indicate outflow there of $1-2 \times 10^{5} \mathrm{~m}^{3} \mathrm{~s}^{-1}$, and associated near surface current speeds vary seasonally from less than $20 \mathrm{~cm} \mathrm{~s}^{-1}$ to more than $150 \mathrm{~cm} \mathrm{~s}^{-1}$.

As the water leaves the sound, it once again joins the westward flowing ACC. Studies of the seasonality of the coastal flow have been carried out in this portion of the coast (Johnson et al., 1988 and Luick, 1988). Within this section of coast, outflow from Prince William Sound joins with that portion of the ACC which never entered the sound but rather flowed along the seaward coast of Montague Island. It is here that the transport in the upper $100 \mathrm{~m}$ of water is estimated to be $2 \times 10^{5} \mathrm{~m}^{3} \mathrm{~s}^{-1}$ with a seasonal variation of about $1 \times 10^{5}$ $\mathrm{m}^{3} \mathrm{~s}^{-1}$. Maximum autumn currents of more than 150 $\mathrm{cm} \mathrm{s}^{-1}$ have been measured, and a maximum transport of $1.2 \times 10^{6} \mathrm{~m}^{3} \mathrm{~s}^{-1}$ has been estimated (Royer, 1981). About $60 \mathrm{~km}$ west of Prince William Sound, the zonal coastline is interrupted by a cape, and the coastal flow is diverted southward by the Chiswell Islands (Fig 1.). The ACC can become unstable here, and cross-shore mixing may be enhanced. Westward of the Chiswell Islands, the coastal precipitation and freshwater discharge diminish, and wind direction becomes more variable, resulting in the ACC becoming more variable. For example, Schumacher and Reed (1980) report typical speeds of $13-30 \mathrm{~cm} \mathrm{~s}^{-1}$, though in October 1978 they found an extreme computed flow of $133 \mathrm{~cm} \mathrm{~s}^{-1}$ relative to $100 \mathrm{~m}$. Most of the ACC enters lower Cook Inlet through Kennedy and Stevenson Entrances while the remainder flows southward along the eastern side of Kodiak Island. The proportion of water entering lower Cook Inlet depends on the strength of the coastal current and upon local atmospheric forcing.

The water on the outer Kodiak shelf becomes well mixed because the shelf is quite shallow, coastal freshwater discharge is much less than the northern Gulf, and storm tracks pass over the region causing intense winds with highly variable directions. For example, in March and October 1978, there were no vertical gradients of water properties over Portlock Bank (Reed and Schumacher, 1986) whereas within the ACC upstream of Kodiak Island, vertical density gradients exist throughout the year (Xiong and Royer, 1984). Circulation on the outer shelf is very sluggish (a few $\mathrm{cm} \mathrm{s}^{-1}$ ) and tends to follow bottom topography. There is usually cyclonic (counterclockwise) curvature flow over the troughs and anticyclonic flow over the shoal areas such as Portlock and Albatross Banks. Tidal currents can be significant relative to the mean flow. The Alaska Current serves as a dynamic outer boundary along the shelf break for the shelf regime. Its speeds range from $50-100 \mathrm{~cm} \mathrm{~s}^{-1}$ and direction is controlled by bottom topography (Lagerloef, 1983). This western boundary current with a $10-15 \times 10^{6} \mathrm{~m}^{3} \mathrm{~s}^{-1}$ transport (Reed et al., 1980; Royer, 1981) is usually located within $70 \mathrm{~km}$ of the shelf break, though significant displacements have been observed (Royer and Emery, 1987). Deep ocean transport here is one to two orders of magnitude greater than the coastal flow, though the surface currents are quite similar.

In contrast to the outer Kodiak shelf, most of the flow entering lower Cook Inlet has high speeds associated with the ACC. The currents follow the bottom topography across lower Cook Inlet from east to west, with maximum observed speeds of $40 \mathrm{~cm} \mathrm{~s}^{-1}$ in September. After the current crosses the inlet, it turns southward near the western side where maximum speeds are found in summer, about $15-20 \mathrm{~cm} \mathrm{~s}^{-1}$ driven by a lateral estuarine-like flow (Muench et al., 1981). There is a well-established surface convergence off Cape Douglas as the flow enters Shelikof Strait. Tidal currents here are significant relative to the mean flow.

Southwest flow direction down the western side of Shelikof Strait is controlled by topography, and speed becomes more variable as the flow proceeds southwestward. Peak speeds in autumn are $60-80 \mathrm{~cm} \mathrm{~s}^{-1}$, with summervalues abouthalf of this. A weaknortheastward flow counter to the general southwestward flow has been observed occasionally in the southern portion of the strait near Kodiak Island. Winter currents are persistent, whereas reversals occur in summer. The flow follows topography out of lower Shelikof Strait and across the shelf, and some of the coastal flow joins the Alaska Current. Compared with the mean current, the tidal component here is negligible (Muench and Schumacher, 1980).

Coastal circulation beyond Kodiak Island lacks the large freshwater influx and steady wind that forces the coastal current upstream in the northern gulf. In the absence of these driving mechanisms and in the presence of island groups and complicated bottom topography, the ACC spreads laterally across the shelf as it 
moves southwestward along the Alaska Peninsula. Here the density gradient between the central gulf and the coastal water is greatest at the shelf break, and this salt gradient provides additional baroclinic forcing for the Alaska Current. There is also evidence that a portion of the ACC enters the Bering Sea through Unimak Pass (Schumacher et al., 1982).

The Spill ${ }^{+}$

Prior to midnight on March 23, 1989, M/T Exxon Valde $z$ altered its course in Prince William Sound to avoid ice that was drifting southeast out of Columbia Bay into the southbound shipping lane (Richter, 1990). Shortly after 0004 (Alaska Standard Time) on March 24, 1989, it ran aground about one mile off Bligh Reef in northern Prince William Sound (Fig. 1). Within thirty-six hours, 242,000 barrels of oil had been released according to the Coast Guard (Richter, 1990). At 0038 Exxon Valdez reported drizzle with a $10-\mathrm{knot}$ wind, slight seas and visibility of ten miles. At 0727 the initial daylight aerial reconnaissance revealed an oil slick 1,000 feet wide and four to five miles long. At 0930, the slick was reported to be two miles wide and three miles long, oriented south-southwest of the reef. At noon on March 24, under clear, calm conditions with winds of about $10 \mathrm{kt}$, the slick had spread to be five miles long and three miles wide. Seas were about one foot. By 1310, about a half day after the grounding. approximately 200,000 barrels of oil had been released and the winds were from the north at $10 \mathrm{kt}$. At 1434, it was reported that the oil had stopped leaking.

Day 2 (March 25) of the spill began with light and variable winds with air temperatures in the mid-30s. At 0824 , it was reported that oil was once again leaking from Exron Valdez. The winds increased to $15 \mathrm{kt}$ from the northeast. At the end of the day, the leading edge of the spill was estimated to be 16.5 miles southwest of Bligh Reef.

Day 3 (March 26) began with calm weather, and the oil was still lying offshore of the beaches. At 2000 winds had increased to $25 \mathrm{kt}$ from the northeast in Valdez Arm. There were also higher gusts reported, and the winds increased to gale force during the night with wind speeds in excess of $60 \mathrm{kt}$ reported for the region.

Onday 4(March 27) at Exxon Valdez,42-knot winds shifted; the streamers reached Seal Island. By 1100 the winds had diminished to $30-40 \mathrm{kt}$, and the seas were about four feet. At the end of day 4, the leading edge of the slick was thirty-seven miles southwest of Bligh Reef and moving at about 20.5 miles per day.

Overnight between days 4 and 5, the winds again increased to $70 \mathrm{kt}$, and by 1200 on March 28 , the leading portion of the oil was reported to be forty miles long and three to twelve miles wide moving south- southwest. During the remainder of the day, the weather improved with the winds at 1800 being $25 \mathrm{kt}$. By the end of day 5, the slick was fifty-two miles from Bligh Reef, having traveled about fifteen miles in one day.

On day 10 (April 2), it was reported that the oil was still leaking and that the slick had entered the Gulf of Alaska. The slick was twelve miles southwest of the southern tip of Montague Island. Streamers were also reported in Bainbridge and Prince of Wales Passages located to the northwest of Montague Strait. By day 11 (April 3), the oil front was four to five miles offshore of Resurrection Bay. Forty days (May 2) after the accident, oil was reported on the eastern shore of the Alaska Peninsula, 470 miles southwest of Bligh Reef (Richter, 1990).

The distribution of the spilled oil has been modeled using available winds and currents. The model has been "corrected" by incorporation of actual sightings of the spilled oil (Galt and Payton, 1990). Their model indicates the oil within Prince William Sound was confined to the western half of the sound to the south of Bligh Reef. The winds and water circulation acted together to transport the oil in this direction (Venkatesh. 1990). Floating oil never came close to Valdez or Cordova but instead followed the general circulation pattern that carried it away from these harbors. The northerly winds on days 3 and 4 helped keep surface oil from entering the upper reaches of Prince William Sound.

Was the movement of the Exxon Valdez oil spill unexpected? To illustrate and to better estimate the near-surface coastal circulation in the region, satellite tracked drifters drogued at 3-m depth were released at various locations between Bligh Reef and Shelikof Strait from autumn 1989 through spring 1990. The shallowness of these drogues was an attempt to approximate the path of spilled oil debris such as mousse (a water-in-oil emulsion which has different physical properties than the starting crude (Anonymous, 1985 , p. 280)) and tarballs. It is uncertain to what extent this was achieved, and this limitation should be considered in comparisons with the actual oil trajectory. The paths of the drifters (Fig. 3, p. 8) illustrate the previous discussion of the circulation within the sound and along the coast of this region. Nine of the drifters released in Prince William Sound never exited. They either ran aground or ceased transmitting. However, they all followed the general pattern of southwest flow. No drifters exited through Hinchinbrook Entrance. One became incorporated in the cyclonic gyre of the central sound. Two drifters released near Bligh Reef traveled southwestward and closely resembled the path of the original spill. It should be noted here that these drifters were released in fall or later, at least six months

\footnotetext{
${ }^{\dagger}$ In this section, non-metric units are used because these were the units of the original measurements, which were most commonly
} estimates. $1 \mathrm{mile}=1.85 \mathrm{~km} ; 1 \mathrm{kt}=0.515 \mathrm{~m} \mathrm{~s}^{-1} ; 1$ foot $=0.305 \mathrm{~m} ; 1$ barrel $=42$ gallons $=158.98$ liters.

Within thirty-six

hours, 242,000 barrels

of oil had been

released. 


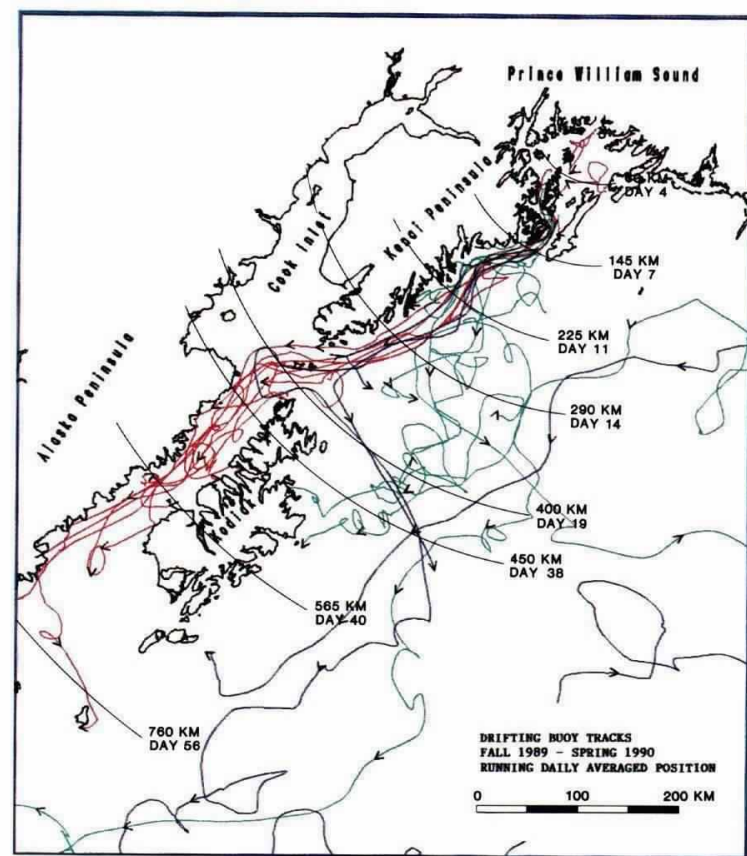

Fig. 3: Running daily mean trajectories of near-surface satellite tracked drifters released between September 1989 and April 1990. Isopleths of leading edge of oil spill are from Richter (1990, p. 62).

after the original spill, and yet had trajectories similar to the spilled oil.

Eighteen other drifters released in Prince William Sound entered the Gulf of Alaska and the ACC, then tended to remain in the coastal flow until its southward diversion by the Chiswell Islands. It was here that strong wind events displaced some drifters (five) offshore, removing them from the ACC. The thirteen remaining drifters headed for the Barren Islands where three of them were blown offshore, across the shelf prior to entering Cook Inlet. The remaining buoys crossed lower Cook Inlet with little or no excursion up the inlet and then migrated along the western side of Shelikof Strait, mimicking the oil spill trajectory. Some drifters followed eddy-like trajectories in the southwestern end of Shelikof Strait.

Of those drifters that left the ACC, three entered the deep ocean circulation of the Gulf of Alaska. Others traced the sluggish flow on the outer Kodiak shelf. One transited out of Shelikof Strait, and another ran aground on Chirikof Island.

In comparison with coastal flows observed elsewhere, this circulation is remarkable in its steadiness. There is a very high likelihood that any materials released in the northern Gulf of Alaska will follow the path represented by these drifters. The drifter speeds were greater than those of the spill, sometimes in excess of $150 \mathrm{~cm} \mathrm{~s}^{-1}$, but are consistent with historical observations for that time of the year.

From prior coastal flow studies it seemed highly probable that the Kodiak Island area would be in the path of the oil spill. For this reason, the circulation around Kodiak Island was measured during September-October 1989. An RD Instruments $300 \mathrm{kHz}$ acous-

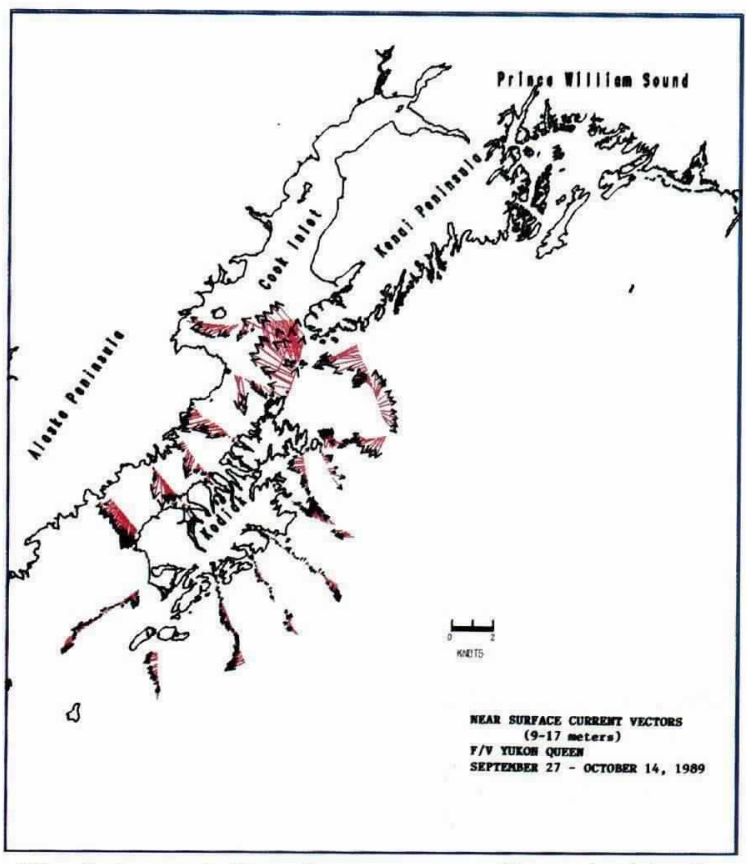

Fig. 4: Acoustic Doppler current profiler velocities for September-October 1989 near Kodiak Island. Averaged over $9-17 \mathrm{~m}$ depth.

tic Doppler current profiler (ADCP) was installed on F/V Yukon Queen, and transects were conducted orthogonal to shore. The 9-17 $\mathrm{m}$ depth-averaged velocities (Fig. 4) confirm the relatively weak flow on the outer Kodiak shelf in the vicinity of Albatross Bank. A portion of the well-organized flow of the Alaska Current is evident off the southeastern tip of Kodiak Island. The weak circulation on the eastern shelf was in contrast to very strong southwestward flow through Shelikof Strait. Most of the coastal flow at this time was westward through Kennedy and Stevenson entrances. Strong nearshore currents associated with the ACC were not present on the eastern side of Kodiak Island. This confirms earlier studies that reported sluggish flow over these banks and troughs (Lagerloef, 1983; Reed and Schumacher, 1986). The path of the oil spill and its spreading rate were consistent with prior knowledge. These conclusions are confirmed by the drifter and ADCP observations.

Were conditions during and after the spill typical for the region? From historical circulation measurements, it has been established that the flow responds to wind stress and freshwater discharge (Johnson et al., 1988). In comparison with earlier years, the freshwater discharge in March 1989 (Fig. 5) was the least ever for the fifty-nine years for which these calculations have been made. Discharges for April and May were also below normal, suggesting that during those months the circulation component driven by freshwater was less intense than normal. By June the discharge was back to normal and followed the normal annual cycle for the remainder of the year. The very low discharge rates for March could have influenced the circulation of Prince William Sound so that the "normal" counterclockwise circulation 


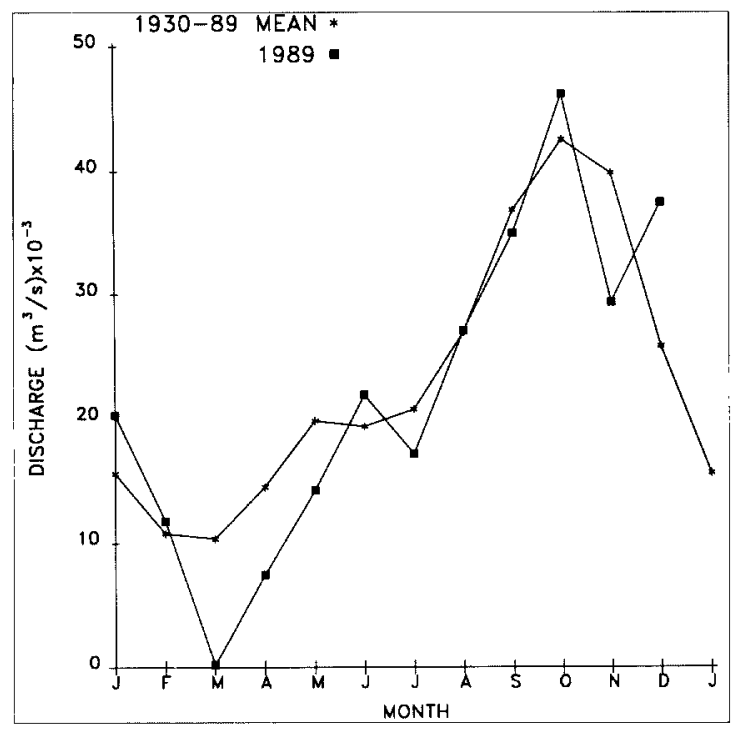

Fig. 5: Discharge of freshwater into the northern Gulf of Alaskafor 1989 with 1931-88averages (afterRoyer. 1982).

might have been reduced or absent. This circulation tends to clear the calving ice from Columbia Bay and other glaciers in the northern sound from the oil tanker shipping lanes. With decreased water circulation, local winds will exert proportionally more influence on the paths of the ice. Diminished circulation and light, local northwesterly winds could place ice in the shipping lanes, creating the need for the tanker's diversion. The winds were light and northerly for several days after the spill, which moved the spill southward where it entered a region of stronger westward flow. Later, gale force winds contributed to the rapid southwestward movement of the spill and the formation of mousse.

Surface winds are important for direct drift of the oil but also affect ocean circulation by locally altering sea level slopes and redistributing the mass field. Venkatesh (1990) evaluated the relative influences of the currents and winds on the oil spill trajectory and concluded that these two factors, working in combination, resulted in a drift that was three to four times that of either of the two influences alone.

Were the winds in this region typical before, during and after the spill? Our method of comparison utilizes the daily upwelling index at $60^{\circ} \mathrm{N}, 146^{\circ} \mathrm{W}$ (Fig. 6 , upper panel). The index is a measure of the onshoreoffshore component of the Ekman transport and is calculated in the same manner as Bakun (1973). The average Ekman transport for 1946-73 has been subtracted to yield anomalies (Fig. 6, lower panel). The anomalies for January and February 1989 were positive, indicating less intense alongshore wind stress than normal. For March, downwelling was greater than normal, but most of this anomaly is attributed to winds during the first week of the month. For the months

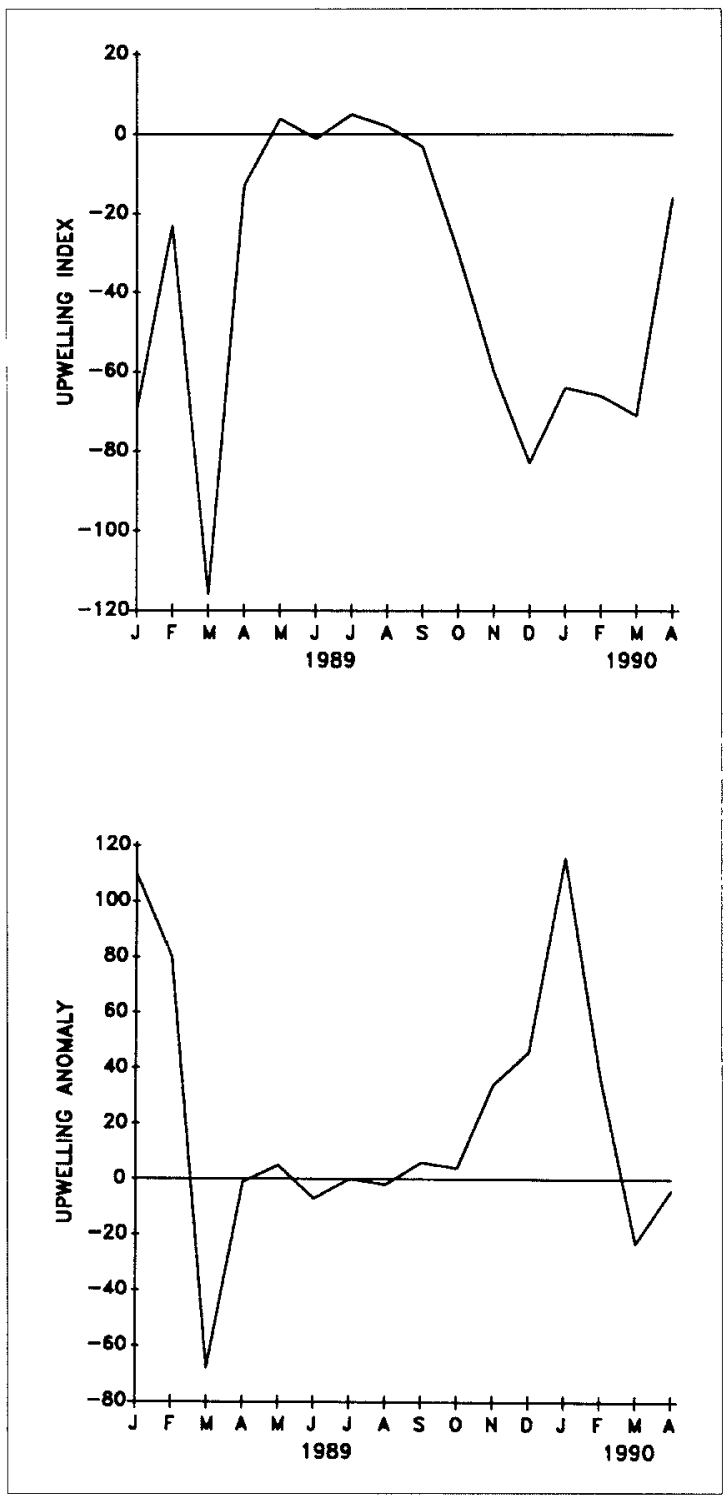

Fig. 6: Upwelling index for $60^{\circ} \mathrm{N}, 146^{\circ} \mathrm{W}$ for 1989 (upper panel) and the upwelling index anomalies (lower panel). (Units are $m^{3} \mathrm{~s}^{-1} / 100 \mathrm{~m}$ of coastline.)

following the spill, the wind stresses were very close to normal with weak downwelling in April and weak upwelling in May. The wind stress remained close to normal (weak upwelling in summer) until November 1989 when a three-month period of less intense than normal downwelling began.

Coastal transports in the northern Gulf of Alaska following the spill were probably slightly less than their normal seasonal means. The spill occurred at the minimum in the seasonal circulation cycle. The average speed of advancement of the leading edge of the spill was $25 \mathrm{~cm} \mathrm{~s}^{-1}$ over forty days. If the spill had occurred at any other time of year, the rate of advancement would have been much greater; as much as $75-100 \mathrm{~cm} \mathrm{~s}^{-1}$ in fall. 


\section{Summary and Conclusions}

The coastal circulation of the northwest Gulf of Alaska and Prince William Sound served as a conduit for oil spilled from M/T Exxon Valdez. The oil entered a current system that carried it hundreds of kilometers along the coast. Downwelling favorable winds which move surface waters onshore and freshwater discharges which tend to move surface waters offshore create a coastal convergence that is remarkable in its constancy. Subsequent drifter and ADCP studies have confirmed the steadiness of the flow. The floating oil did not remain in the vicinity of the accident for more than a few days. If any buoyant materials are introduced into Prince William Sound in the future, they will most likely follow a trajectory similar to the Valdez spill. The speeds will depend upon the time of year, but they will probably be greater than those that transported the original spill.

The ultimate fate of some of the spilled oil is unknown. It has been estimated that approximately $30 \%$ of the oil was lost to weathering processes within the first two weeks of the spill (Galt and Payton, 1990). The balance either came ashore or remained in the water column. To be removed from the surface, the floating oil must increase its specific gravity to be greater than the seawater. Prudhoe Bay crude has a relatively low density (Anonymous, 1985), and in order for it to sink, it must bond with sediments. The suspended fine-grained sediment load within the freshwater discharge of the northern Gulf of Alaska is very high (Feely et al., 1979); however, the rate of bonding of the oil to these sediments is unknown. In any case, the high current speeds will reduce the concentration of any potentially oiled sediments in the northern Gulf of Alaska and especially Prince William Sound. The swift Alaska Coastal Current has and will continue to flush the waters of Prince William Sound and the adjacent coastal environment.

\section{Acknowledgements}

The analysis of the historical oceanographic data was funded by Exxon through contracts to the University of Alaska, Fairbanks, and Science Applications International Corporation. We thank all of the researchers who gathered these data over the years. The archive search was carried out by Chirk Chu at the University of Alaska. The drifting buoy and Kodiak Island ADCP studies were carried out by Exxon Production Research Company with the assistance of Exxon Company, U.S.A., Alaska Operations and Brown and Caldwell Consulting Engineers. The drifter and ADCP data were processed and mapped by Roy Cuellar, Jr., at Exxon Production Research Company. This is Institute of Marine Science Contribution No. 834.

\section{References}

Ahlnaes, K., T.C. Royer and T.H. George, 1987: Multiple dipole eddies in the Alaska Coastal Current detected with Landsat thematic mapper data.J. Geophys. Res., 92(Cl2), 13,04113-047. and T.C. Royer, 1989: Application of satellite visible band data to high latitude oceans. Remote Sens. Environ., 28, 85-93.

Anonymous, 1985: Oil in the Sea: Inputs, Fates and Effects. National Academy Press, Washington, D.C., 601 pp.

Bakun, A., 1973: Coastal upwelling indices, west coast of North America. 1946-71. Tech. Rep. NMFS SSRF-671, National Oceanic and Atmospheric Administration. Seattle, WA. 103 pp.

Feely, R.A., E.T. Baker, J.D. Schumacher, G.J. Massoth and W.M. Landing, 1979: Processes affecting the distribution and transport of suspended matter in the northeast Gulf of Alaska. Deep-Sea Res., 26, 445-464

Galt.J.A. and D.L.Payton, 1990: Movement of spilled oil from the Exxon Valdez. In: Proceedings of Marine Mammal Conference, Anchorage, Alaska, 15 pp.

Hampton, M.A., P.R. Carlson, H.J. Lee and R.A. Fealey, 1986: Geomorphology, sediment and sedimentary processes. In: The Gulf of Alaska. Physical Environment and Biological Resources, U.S. Dept. of Commerce, OCS Study, MMS 86-0095, 93-144.

Johnson, W.R., T.C. Royer and J.L. Luick, 1988: On the seasonal variability of the Alaska Coastal Current.J.Geophys.Res., $93,12,423-12,437$

Lagerloef, G., 1983: Topographically controlled flow around a deep trough transecting the shelf off Kodiak Island. Alaska J. Phys. Ocean., 11, 139-146.

Luick, J.L., 1988: On the dynamics of the Alaska Coastal Current. Ph.D. Thesis, University of Alaska, Fairbanks. 111 pp.

Muench, R.D. and C.M. Schmidt, 1975: Variations in the hydrographic structure of Prince William Sound. IMS Report R75-1, Institute of Marine Science, Fairbanks. Alaska, 135 pp.

and J.D. Schumacher, 1980: Physical Oceanography and meteorological conditions in the northwest Gulf of Alaska. NOAA Tech. Memo. ERL/PMEL-22, 147 pp.

J.D. Schumacher and C.A. Pearson, 1981: Circulation in the lower Cook Inlet, Alaska. NOAA Tech. Memo. ERL/ PMEL-28, 26 pp.

Reed, R.K.. R.D. Muench and J.D. Schumacher, 1980: On baroclinic transport of the Alaskan Stream near Kodiak Island. Deep-Sea Res.. 27, 509-523. and J.D. Schumacher, 1986: Physical Oceanography. In: The Gulf of Alaska; Physical Environment and Biological Resources. U.S. Dept. of Commerce. OCS study, MMS 86-0095, 57-75.

Richter, C.K.. 1990: T/V Exxon Valdez oil spill chronology. Appendix N, In: Spill: The Wreck of the Exxon Valder, Alaska Oil Spill Commission, Volume IV, 224 pp.

Royer, T.C.. 1981: Baroclinic transport in the Gulf of Alaska. Part II. Fresh water driven Alaska Coastal Current. J.Mar. Res. $39,251-266$.

1982: Coastal fresh water discharge in the Northeast Pacific. J. Geophys. Res., 87, 2017-2021.

D.V. Hansen and D.J. Pashinski, 1979: Coastal flow in the northern Gulf of Alaska as observed by dynamic topography and satellite-tracked drogued drift buoys. $J$. Phys. Ocean., 9. 785-801.

and W. J. Emery, 1987: On the circulation in the Gulf of Alaska, 1981. Deep-Sea Res., 34, 1361-1377.

Schumacher, J.D. and R.K. Reed, 1980: Coastal flow in the northwest Gulf of Alaska: The Kenai Current. J. Geophys. Res. 85.6680-6688.

,C.A. Pearson and J.E. Overland, 1982: On the exchange of water between the Gulf of Alaska and the Bering Sea through Unimak Pass. J. Geophys. Res., 87, 5785-5795.

Venkatesh, S., 1990: Model simulations of the drift and spread of the Exxon Valdez oil spill. Atmos.-Ocean, 28, 90-105.

Xiong, Q, and T.C. Royer, 1984: Coastal temperature and salinity observations in the northern Gulf of Alaska, 1970-1982.J. Geophys. Res., 89, 8061-8068. 